\title{
Multiple neuroendocrine tumor of the small bowel: a case report and a review of literature
}

\author{
Lumir Kunovsky ${ }^{1,2}$, Milan Dastych ${ }^{1}$, Oldrich Robek ${ }^{2}$, Roman Svaton², Jakub Vlazny ${ }^{3}$, Jakub Husty ${ }^{4}$, \\ Michal Eid ${ }^{5}$, Karolina Poredska' ${ }^{1}$, Petr Kysela ${ }^{2}$, Zdenek Kala ${ }^{2}$ \\ 'Department of Gastroenterology, University Hospital Brno Bohunice, Faculty of Medicine, MU, Brno \\ 2Department of Surgery, University Hospital Brno Bohunice, Faculty of Medicine, MU, Brno \\ ${ }^{3}$ Department of Pathology, University Hospital Brno Bohunice, Faculty of Medicine, MU, Brno \\ ${ }^{4}$ Department of Radiology, University Hospital Brno Bohunice, Faculty of Medicine, MU, Brno \\ ${ }^{5}$ Department of Hematology, Oncology and Internal medicine, University Hospital Brno Bohunice, Faculty of Medicine, MU, Brno
}

\section{Summary}

Primary malignant tumors of small bowel constitute only about $1-2 \%$ of all gastrointestinal neoplasms. Although neuroendocrine tumors (NETs) are relatively rare, they still represent the second most common malignancy of the small bowel (after adenocarcinoma). Clinical manifestations include abdominal pain, bowel obstruction, diarrhea, weight loss and bleeding. The differential diagnosis of obscure gastrointestinal bleeding can sometimes be challenging for endoscopy as well as for radiology methods. We present the case of an 80-year-old man suffering from severe hypochromic anemia. Routine endoscopic methods did not show any appropriate pathology. Finally, a single ulcerative infiltration of the ileum was diagnosed by capsule endoscopy (CE). CT enterography did not reveal any other lesions. In accordance with a positive chromogranin A, endoscopic and radiologic methods, a suspicion of NET was expressed. During the surgery, 7 lesions were found and a resection of $120 \mathrm{~cm}$ of ileum was performed. The histology confirmed a diagnosis of NET grade 1, with a total number of 15 NET lesions in the specimen. The following octreotide scan did not show any residual infiltration. We present a patient with 15 NET lesions in the ileum diagnosed by CE and successfully cured by surgical resection of the ileum.

Key words: capsule endoscopy - carcinoid syndrome - gastrointestinal carcinoids - neuroendocrine tumor obscure gastrointestinal bleeding - small bowel - surgery

\section{Mnohočetné postižení tenkého střeva neuroendokrinním tumorem:}

\section{kazuistilka a přehled literatury}

\section{Souhrn}

Maligní tumory tenkého střeva tvoří jen asi 1-2 \% ze všech nádorů gastrointestinálního traktu. Ačkoli neuroendokrinní tumory (NETs) jsou relativně vzácné, tak i přesto představují druhou nejčastější malignitu tenkého střeva (hned po adenokarcinomu). Klinicky se projevují bolestí břicha, střevní obstrukcí, průjmy, úbytkem na váze či krvácením. Diferenciální diagnostika skrytého gastrointestinálního krvácení může být někdy výzvou jak pro metody endoskopické, tak radiologické. Prezentujeme případ 80letého pacienta došetřovaného pro těžkou mikrocytární anémii. Základní endoskopické metody neobjasnily zdroj skrytého krvácení. Nakonec pomocí kapslové endoskopie (CE) byla diagnostikována izolovaná ulcerace ilea s navalitými okraji. CT enterografie nezachytila žádnou další lézi. Vzhledem k pozitivním hodnotám chromograninu A, nálezu na endoskopických a zobrazovacích metodách bylo vysloveno podezření na NET tenkého střeva. Během operace bylo zjištěno 7 ložisek NET tenkého střeva a byla provedena resekce $120 \mathrm{~cm}$ ilea. Dle definitivní histologie bylo v preparátu nalezeno celkem 15 ložisek NET grade 1. Kontrolní octreoscan neodhalil žádné další reziduální ložisko. Představujeme př́ípad pacienta s celkem 15 ložisky NET tenkého střeva diagnostikovaného pomocí CE s následnou úspěšnou resekcí ilea.

Klíčová slova: gastrointestinální karcinoid - chirurgie - kapslová endoskopie - karcinoidový syndrom neuroendokrinní tumor - skryté krvácení do gastrointestinálního traktu - tenké střevo 


\section{Introduction}

Primary small bowel malignant tumours comprise only $1-2 \%$ of all gastrointestinal neoplasms. Neuroendocrine tumours (NETs) represent a relatively rare subgroup of malignant neoplasms. Despite this fact, NETs are the second most common malignant tumours of the small bowel [1-3]. NET can be often asymptomatic for a long time, sometimes can present with obscure gastrointestinal bleeding (OGIT) and the diagnostics can be challenging as for endoscopic as well as radiologic tools [4-7]. An increase of small bowel NETs incidence has been reported recently, not due to a real incidence rise but rather due to better diagnostic methods $[6,8,9]$.

\section{Case report}

Our patient is an 80-year-old polymorbid man investigated for a severe anemia (hemoglobin level of $53 \mathrm{~g} / \mathrm{L}$ ). His case history includes chronic ischemic heart disease, heart attack, aortic valve replacement, cardiac rhythm disturbances, diabetes mellitus and prostatectomy for adenocarcinoma.

Esophagogastroduodenoscopy revealed just a mild erosive gastropathy. During colonoscopy, only diverticulosis of the sigmoid colon was diagnosed, and four small polyps were removed by endoscopic polypectomy (tubular adenomas).

Due to persistent anemia, the patient underwent enteroscopy, where no significant pathology was discovered. Subsequently, capsule endoscopy (CE) was performed, finding a $12 \times 6 \mathrm{~mm}$ isolated ulceration in the ileum, with thickened edges giving the impression of an exulcerated submucosal formation of $2 \mathrm{~cm}$ in total (fig. 1a, 1b).

Due to the positive values of chromogranin A $(207.3 \mu \mathrm{g} / \mathrm{L}$, reference range $<50$ ) and the findings of endoscopic and imaging methods - CT enterography (fig. 2a, 2b),

Fig. 1a, 1b. CE showing an ulceration with thickened edges of $2 \mathrm{~cm}$ in size
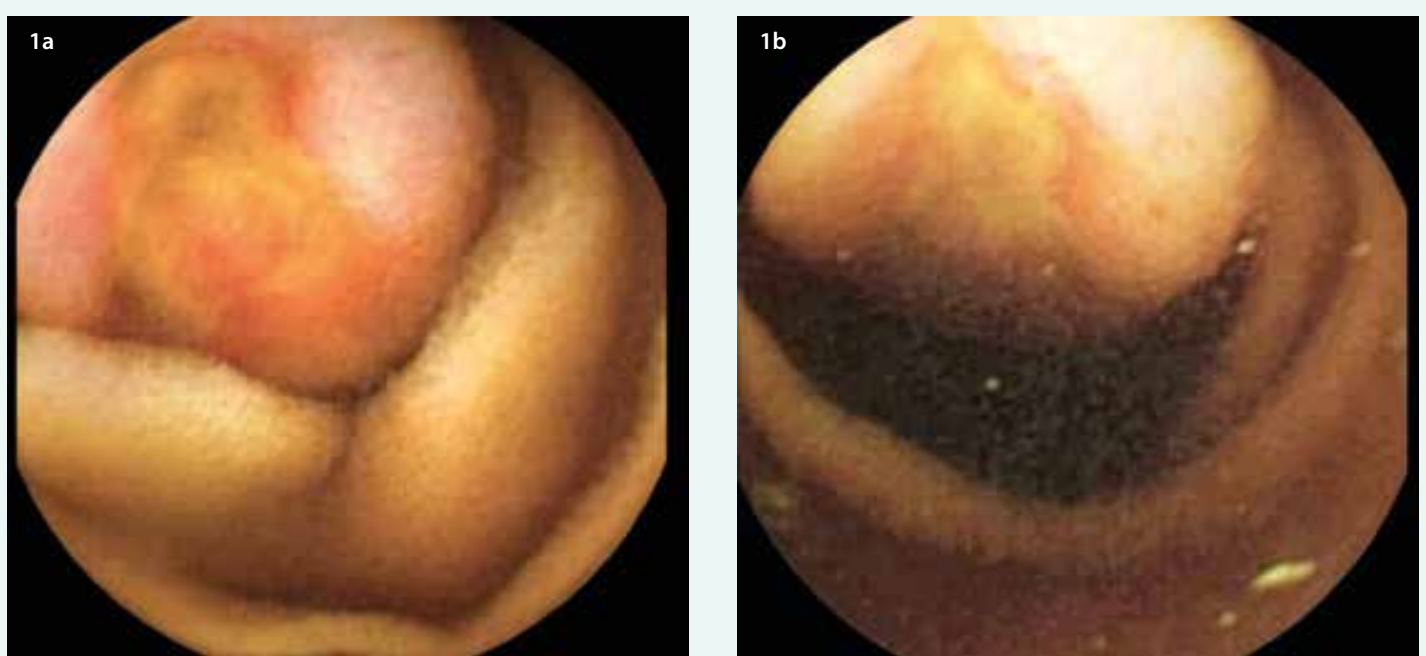

Fig. 2a, 2b. Contrast enhanced CTa a (coronal scan) and b (transversal scan) hypervascularised lesion on ileal bowel loop (red arrow)
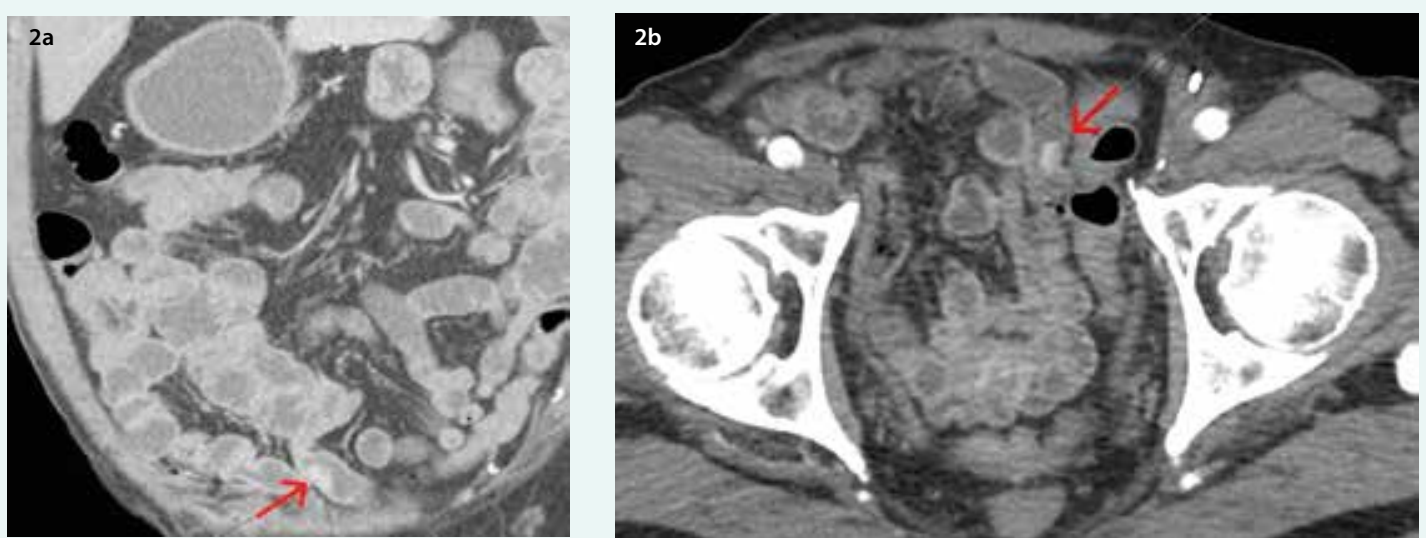
we expressed a suspicion of a NET of the small intestine. During surgery (fig. 3), seven suspect rigid small intestine lesions were palpably detected, and a resection of $120 \mathrm{~cm}$ of the ileum was performed. According to definitive histology (fig. 4, 5, 6a, 6b), a total of 15 NET grade

\section{Fig. 3. Peroperative view of $\mathbf{2}$ round-shaped lesions}

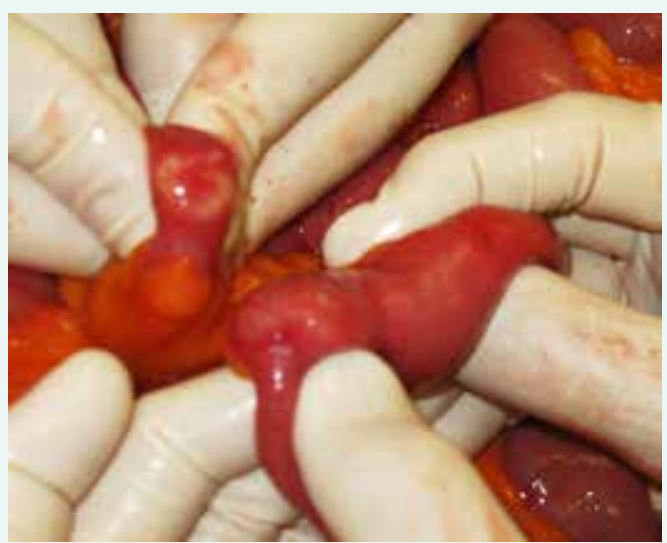

Fig. 4. Specimen of ileum after fixation in formaldehyde. Lesions of NET marked by arrows

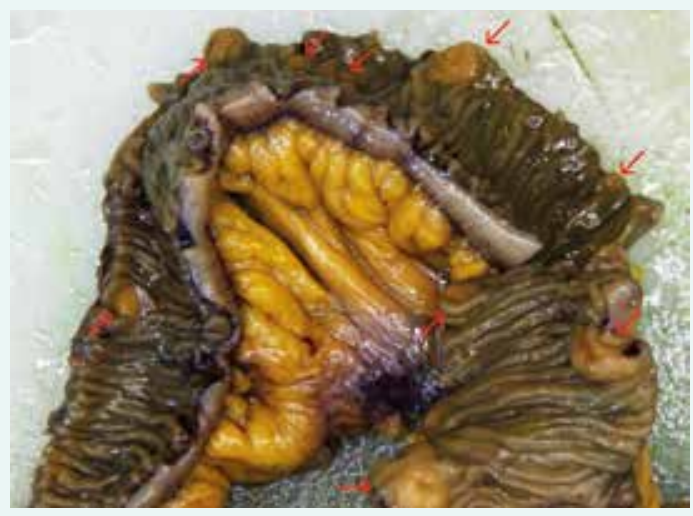

Fig. 5. Histological section: NET infiltrating submucosa of the small bowel wall, HE staining, 200x

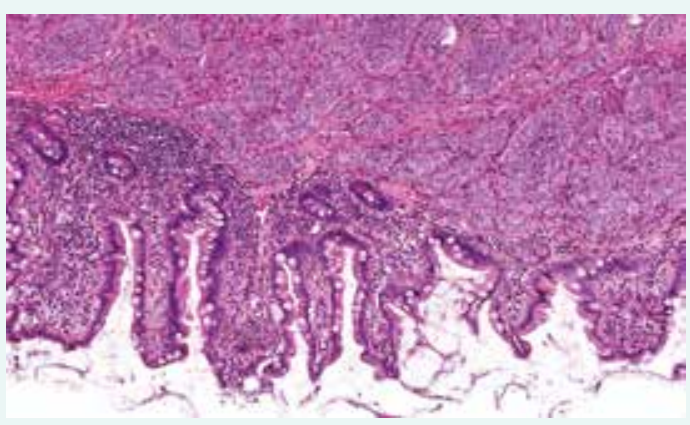

1 lesions with the predominance of submucosa and muscularis propria (T3) were found. Metastases were present in 6 regional lymph nodes (total 12 examined lymph nodes). In the postoperative period, a following octreotide scan was performed without residual lesion finding. From an oncological point of view, only observation without subsequent adjuvant oncological treatment will be introduced.

\section{Discussion}

NETs located in the duodenum up to $1 \mathrm{~cm}$ in size can be treated endoscopically and are mostly isolated lesions $[10,11]$. On the other hand, surgical treatment is recommended for NETs in the jejunoileum. They have a greater propensity to metastasize and NETs in this localization can even form more lesions $[2,6,8]$. Multiple lesions may be found in up to $40 \%$ of cases [8]. Small bowel NETs may initially behave asymptomatically, and even small tumors under $1 \mathrm{~cm}$ tend to form lymph node metastases relatively early (in $20-30 \%$ of cases). For NETs larger than $2 \mathrm{~cm}$, the risk of metastatic involvement of regional lymph nodes increases to over $80 \%$. With primary tumor size up to $2 \mathrm{~cm}$, the incidence of liver metastases is reported in up to $20 \%$ of patients (for sizes greater than $2 \mathrm{~cm}$ in more than $40 \%$ of patients) [1,5]. The carcinoid syndrome, which occurs in $20-30 \%$ of pa-

Fig. 6a. Histological section: Solid, insular masses of monotonous small round cells positive for chromogranin, immunohistochemical staining, 200x

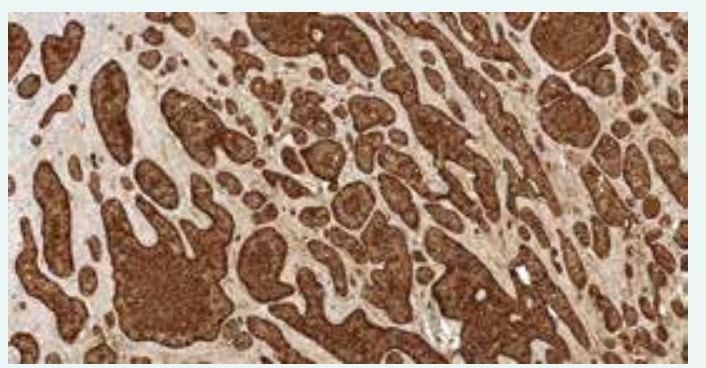

Fig. 6b. Histological section: Proliferation Ki67 index is less than 2\%, 1 mitoses/10 high-power fields, immunohistochemical staining, 200x

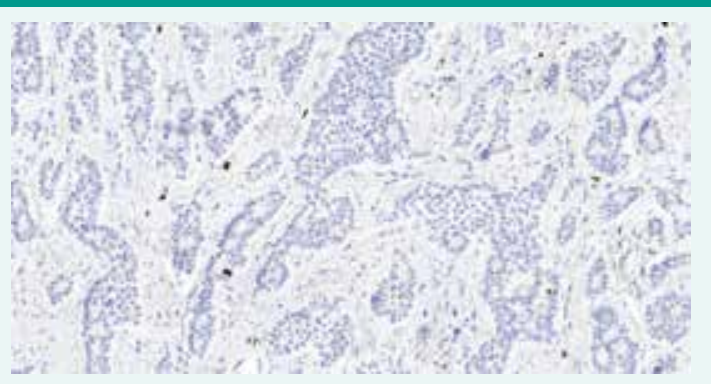


tients with a NET of the small intestine, is almost always (around 95\%) associated with the presence of liver metastases $[4,6,8]$.

When diagnosing NETs, their tendency to extraluminal proliferation may be problematic. This was the case with our patient, most of whose lesions tended to infiltrate submucosa and muscularis propria. In the diagnosis of small intestine tumors, CE, double-ballon enteroscopy and CT enterography are usually compared. In comparative studies of these methods in the diagnosis of small intestine tumors, the yield appears to be similar (although in case of NETs, CE has slightly better results) [8,12-15].

On the other hand, a certain disadvantage of CE in the diagnosis of NETs may be their tendency toward extraluminal spreading [5]. The combination of these 3 methods in the diagnosis of OGIB and small intestine tumors [15-19] seems to be ideal. In our case, only one lesion was identically visible on CE and CT enterography. Other lesions were detected by palpation during surgery and from the definitive histology. The following octreotide scan did not reveal any other residual lesions. Therefore there is no indication of systemic treatment.

Even if in our patient one lesion of $2 \mathrm{~cm}$ in size and another 14 lesions occurred ranging in size from $0.5 \mathrm{~cm}$ to $2 \mathrm{~cm}$, the carcinoide syndrome or liver metastasis were not present. Only positive regional lymph nodes metastases were evaluated in the specimen. There are no data for the adjuvant treatment.

5 -year survival rate in patients with NET and the regional lymph node involvement reaches $70-90 \%$ after curative surgery with lymphadenectomy $[1,4,20]$.

\section{Conclusion}

We present an 80-year-old man with OGIB. In our rare case, a patient with 15 lesions of NET in the ileum was diagnosed by CE and successfully cured by surgical resection of the ileum.

\section{Supported by Ministry of Health, Czech Republic - conceptual development of research organization (FNBr, 65269705).}

\section{References}

1. Bonekamp D, Raman SP, Horton KM et al. Role of computed tomography angiography in detection and staging of small bowel carcinoid tumors. World J Radiol 2015; 7(9): 220-235. Dostupné z DOI: <http:// dx.doi.org/10.4329/wjr.v7.i9.220>.

2. Zonča $P$, Peteja $M$, Richter $V$ et al. Primary malignant small bowel tumors. Rozhl Chir 2016; 95(9): 344-349.

3. Němec $L$, Fabian $P$, Tomášek J et al. Malignant tumors of the small bowel. Rozhl Chir 2017; 96(6): 252-259.

4. Niederle B, Pape UF, Costa F et al. ENETS Consensus Guidelines Update for Neuroendocrine Neoplasms of the Jejunum and Ileum. Neuroendocrinology 2016; 103(2): 125-438. Dostupné z DOI: <http:// dx.doi.org/10.1159/000443170>.

5. Johanssen S, Boivin M, Lochs $\mathrm{H}$ et al. The yield of wireless capsule endoscopy in the detection of neuroendocrine tumors in comparison with CT enteroclysis. Gastrointest Endosc 2006; 63(4): 660-665. Dostupné z DOI: <http://dx.doi.org/10.1016/j.gie.2005.11.055>.

6. Scherübl H, Jensen RT, Cadiot $G$ et al. Neuroendocrine tumors of the small bowels are on the rise: Early aspects and management.
World J Gastrointest Endosc 2010; 2(10): 325-334. Dostupné z DOI: $<$ http://dx.doi.org/10.4253/wjge.v2.i10.325>.

7. Triester SL, Leighton JA, Leontiadis Gl et al. A Meta-Analysis of the Yield of Capsule Endoscopy Compared to Other Diagnostic Modalities in Patients with Obscure Gastrointestinal Bleeding. Am J Gastroenterol 2005; 100(11): 2407-2418. Dostupné z DOI: <http://dx.doi.org/10.111 1/j.1572-0241.2005.00274.x>.

8. Xavier S, Rosa B, Cotter J. Small bowel neuroendocrine tumors: From pathophysiology to clinical approach. World J Gastrointest Pathophysiol 2016; 7(1): 117-124. Dostupné z DOI: <http://dx.doi. org/10.4291/wjgp.v7.i1.117>.

9. Margonis GA, Samaha M, Kim Y et al. A Multi-institutional Analysis of Duodenal Neuroendocrine Tumors: Tumor Biology Rather than Extent of Resection Dictates Prognosis. J Gastrointest Surg 2016; 20(6): 1098-1105. Dostupné z DOI: <http://dx.doi.org/10.1007/ s11605-016-3135-x>.

10. Kim GH, Kim Jl, Jeon SW et al. Endoscopic resection for duodenal carcinoid tumors: A multicenter, retrospective study. J Gastroenterol Hepatol 2014; 29(2): 318-324. Dostupné z DOI: <http://dx.doi. org/10.1111/jgh.12390>.

11. Kimura T, Muguruma N, Goji T et al. Pedunculated duodenal carcinoid successfully removed by endoscopic resection with endoloop. J Dig Dis 2013; 14(7): 402-404. Dostupné z DOI: <http://dx.doi. org/10.1111/1751-2980.12033>.

12. He B, Gong S, Hu C et al. Obscure gastrointestinal bleeding: diagnostic performance of 64-section multiphase CT enterography and CT angiography compared with capsule endoscopy. Br J Radiol 2014; 87(1043): 20140229. Dostupné z DOI: <http://dx.doi.org/10.1259/bjr.20140229>.

13. Kysela $S$, Frajerová $D$, Hadraba $L$ et al. Adenocarcinoma of the small intestine as an unusual source of hypochromic anemia. Gastroenterol Hepatol 2017; 71(4): 333-336.

14. Friedman S. Comparison of capsule endoscopy to other modalities in small bowel. Gastrointest Endosc Clin N Am 2004; 14(1): 51-60. Dostupné z DOI: <http://dx.doi.org/10.1016/j.giec.2003.10.001>.

15. Chu Y, Wu S, Qian Y et al. Complimentary Imaging Modalities for Investigating Obscure Gastrointestinal Bleeding: Capsule Endoscopy, Double-Balloon Enteroscopy, and Computed Tomographic Enterography. Gastroenterol Res Pract 2016; 2016: 8367519. Dostupné z DOI: $<$ http://dx.doi.org/10.1155/2016/8367519>.

16. Zhang ZH, Qiu CH, Li Y. Different roles of capsule endoscopy and double-balloon enteroscopy in obscure small intestinal diseases. World J Gastroenterol 2015; 21(23): 7297-7304. Dostupné z DOI: <http://dx.doi.org/10.3748/wjg.v21.i23.7297>.

17. Heo HM, Park CH, Lim JS et al. The role of capsule endoscopy after negative $C T$ enterography in patients with obscure gastrointestinal bleeding. Eur Radiol 2012; 22(6): 1159-1166. Dostupné z DOI: <http:// dx.doi.org/10.1007/s00330-011-2374-1>.

18. Zhang $\mathrm{Q}, \mathrm{He} \mathrm{Q}$, Liu J et al. Combined use of capsule endoscopy and double-balloon enteroscopy in the diagnosis of obscure gastrointestinal bleeding: meta-analysis and pooled analysis. Hepatogastroenterology 2013; 60(128): 1885-1891.

19. Cellier C. Obscure gastrointestinal bleeding: Role of videocapsule and double-balloon enteroscopy. Best Pract Res Clin Gastroenterol 2008; 22(2): 329-340. Dostupné z DOI: <http://dx.doi.org/10.1016/j. bpg.2007.12.006>.

20. Srirajaskanthan R, Ahmed A, Prachialias A et al. ENETS TNM Staging Predicts Prognosis in Small Bowel Neuroendocrine Tumours. ISRN Oncol 2013; 2013: 420795. Dostupné z DOI: <http://dx.doi.org/10.1155/2013/420795>.

\section{Petr Kysela, M.D., Ph.D. $\triangle$ kysela.petr@fnbrno.cz}

Department of Surgery, University Hospital Brno Bohunice, Faculty of Medicine, Masaryk University

\section{www.fnbrno.cz}

www.med.muni.cz

Doručeno do redakce 11. 4. 2018

Prijato po recenzi 3. 6. 2018 